\title{
Critical Thinking Skills of Students in Teaching Mathematics Using Model Problem-Based Learning
}

\author{
Iskandar Zulkarnain ${ }^{1}$, Elli Kusumawati ${ }^{2}$, Siti Mawaddah ${ }^{3}$ \\ ${ }^{1}$ Department of Mathematics Education, LambungMangkurat University, \\ Banjarmasin, Indonesia \\ Email: hiskzulk@ulm.ac.id \\ ${ }^{2}$ Department of Mathematics Education, LambungMangkurat University, \\ Banjarmasin, Indonesia \\ Email: ellikusumawati@ulm.ac.id \\ ${ }^{3}$ Department of Mathematics Education, LambungMangkurat University, \\ Banjarmasin, Indonesia \\ Email: stmawaddah@ulm.ac.id
}

\begin{abstract}
This study aims to describe the critical thinking skills of class VII B students of SMPN 1 Banjarmasin in learning mathematics using the model of problem-based learning (PBL) in the 2018/2019 study year. The method used in this research is the quantitative descriptive method. The object of research is the students' critical thinking skills. Data collection techniques using test techniques. The instrument used was a written test in the form of description to measure students' critical thinking skills in learning mathematics using the PBL model. The results showed that students' critical thinking skills in learning mathematics using PBL models in VIII grade students of SMPN 1 Banjarmasin in the 2018/2019 academic year were in good qualifications.
\end{abstract}

Keywords: critical thinking, problem-based learning (PBL)

\section{Introduction}

Mathematical critical thinking ability is an essential mathematical ability that is essential and needs to be possessed by students who study mathematics. Several reasons underlie the statement. First, the ability to think mathematically contained in the curriculum and learning objectives of mathematics, among others; train to think logically, systematically, critically, creatively, and accurately and to think objectively, open to face problems in daily life and to face the ever-changing future [1]-[3]. Second, in critical thinking, a person does not easily accept something he receives, without knowing its origin, but he can be held accountable for his opinion accompanied by logical reasons [4]-[7]. Some experts define the term critical thinking with different expressions but contain similar meanings. Ennis defines critical thinking as reasonable reflective thinking and is focused on determining what is believed or done [8][11]. Critical thinking relates to five key ideas namely practical, reflective, reasonable, trust and action. In addition, critical thinking also has four components, namely: clarity, basis, inference and interaction.

Gokhale defines the term critical thinking as thinking that involves the activity of analyzing, synthesizing, and evaluating concepts [12]. In critical thinking, the activities involved in manipulating existing data or information become more meaningful. In mathematics, Glaser explains that mathematical critical thinking includes abilities and dispositions combined with the 
initial knowledge, mathematical reasoning, and cognitive strategies to generalize, prove, and assess reflective mathematical situations [13].

Paying attention to the definition of critical thinking from the experts above, basically, critical thinking is classified as high-level thinking skills, which not only memorize but use and manifestation of materials learned in new situations. However, critical thinking is not equivalent to higher-order thinking skills. In critical thinking, all components of high-level thinking are contained, and also contain dispositions that are not contained in high-level thinking [14].

Critical thinking is a systematic process that allows someone to formulate and evaluate their own beliefs and opinions. Critical thinking is also an organized process that allows one to evaluate the evidence, assumptions, logic, and language that underlies the statement it receives. In critical thinking all abilities are empowered, be it understanding, remembering, distinguishing, analyzing, giving reasons, reflecting, interpreting, looking for relationships, evaluating even making temporary conjectures.

Indicators of mathematical critical thinking ability according to [14] include the following abilities.

a. Interpretation, namely the ability to understand and express the meaning/meaning of the problem.

b. Analysis, namely the ability to identify and conclude relationships between statements, questions, concepts, descriptions, or other forms.

c. Inference, namely the ability to identify and obtain the elements needed in conclusion.

d. Evaluation, which is the ability to access the credibility of statements/ representations and can logically access the relationships between statements, descriptions, questions, and concepts.

e. Explanation, which is the ability to state and justify reasons in the form of evidence, conceptual, methodological, criteria logical, and contextual.

f. Self-regulation, namely the ability to monitor one's cognitive activity, the elements used in problemsolving activities, especially in applying the ability to analyze and evaluate.

In this study, the indicators used to measure critical thinking skills are as follows.

a. Interpretation, namely the ability to understand the problem shown by writing known or asked questions correctly.

b. Analysis, namely the ability to identify the relationships between statements, questions, and concepts provided in the problem shown by making mathematical models correctly and giving explanations correctly.

c. Evaluation, namely the ability to use the right strategy in solving problems, complete and correct in doing calculations.

d. Inference, namely the ability to make conclusions correctly.

Mathematics education instructors at both the secondary and post-secondary levels can enhance students' critical thinking skills by using instructional strategies that actively engage students in the learning process rather than relying on lecture and note memorization [15]. One learning model that can optimize critical thinking skills is the PBL model or problem-based learning. In general problem-based learning presents a variety of authentic and meaningful problems, which can serve as an incentive for students to conduct investigations and inquiry [16], [17]. One of the learning objectives by using the PBL model is to develop thinking skills, then Yazdani [18] states that one of the objectives of the PBL model is to develop the skills of scientific reasoning, critical assessment, literacy information, interpersonal skills, self-direction skills, lifelong learning. Based on this, it appears that learning with PBL is designed to help students develop thinking skills, solve problems so that they become independent and autonomous students.

Table 1. Critical Thinking Guidelines Guidelines

\begin{tabular}{|c|c|c|}
\hline $\begin{array}{l}\text { Indicators } \\
\text { Critical } \\
\text { Thinking }\end{array}$ & Students' Responses to Questions & Score \\
\hline \multirow{5}{*}{$\begin{array}{l}\text { Interpretati } \\
\text { on }\end{array}$} & Do not write the known and the asked. & 0 \\
\hline & Write the known and asked incorrectly. & 1 \\
\hline & $\begin{array}{l}\text { Write down just what is known correctly or } \\
\text { just what is asked exactly. }\end{array}$ & 2 \\
\hline & $\begin{array}{l}\text { Write what is known and asked of the } \\
\text { problem correctly but is incomplete. }\end{array}$ & 3 \\
\hline & $\begin{array}{l}\text { Write what is known and asked of the } \\
\text { problem precisely and completely. }\end{array}$ & 4 \\
\hline \multirow{5}{*}{ Analysis } & $\begin{array}{l}\text { Do not make a mathematical model of the } \\
\text { problem given. }\end{array}$ & 0 \\
\hline & $\begin{array}{l}\text { Make a mathematical model of a given } \\
\text { problem but not right }\end{array}$ & 1 \\
\hline & $\begin{array}{l}\text { Make a mathematical model of a given } \\
\text { problem without explanation. }\end{array}$ & 2 \\
\hline & $\begin{array}{l}\text { Make a mathematical model of the problem } \\
\text { given precisely but there are errors in the } \\
\text { explanation. }\end{array}$ & 3 \\
\hline & $\begin{array}{l}\text { Make a mathematical model of the problem } \\
\text { given correctly and explain it correctly and } \\
\text { completely. }\end{array}$ & 4 \\
\hline \multirow{3}{*}{ Evaluation } & Do not use strategies in solving problems & 0 \\
\hline & $\begin{array}{l}\text { Use strategies that are not appropriate and } \\
\text { incomplete in solving problems. }\end{array}$ & 1 \\
\hline & $\begin{array}{l}\text { Using the right strategy in solving problems } \\
\text { but not complete, or using strategies that are } \\
\text { not right but complete in solving problems. }\end{array}$ & 2 \\
\hline
\end{tabular}




\begin{tabular}{|c|c|c|}
\hline & $\begin{array}{l}\text { Use the right strategy in solving problems, } \\
\text { complete but make mistakes in calculations } \\
\text { or explanations. }\end{array}$ & 3 \\
\hline & $\begin{array}{l}\text { Using the right strategy in solving problems, } \\
\text { complete and correct in doing } \\
\text { calculations/explanations. }\end{array}$ & 4 \\
\hline \multirow{5}{*}{ Inference } & Do not make conclusions. & 0 \\
\hline & $\begin{array}{l}\text { Making conclusions that are not right and do } \\
\text { not fit the context of the problem. }\end{array}$ & 1 \\
\hline & $\begin{array}{l}\text { Making inaccurate conclusions, although } \\
\text { adjusted to the context of the problem. }\end{array}$ & 2 \\
\hline & $\begin{array}{l}\text { Make conclusions correctly, in context but } \\
\text { not complete. }\end{array}$ & 3 \\
\hline & $\begin{array}{l}\text { Make conclusions precisely, contextually } \\
\text { and completely. }\end{array}$ & 4 \\
\hline
\end{tabular}

After the data obtained from the test results of critical thinking skills, the data will be analyzed using quantitative analysis with percentage techniques.

\section{Result and Discussion}

Students' critical thinking skills on the material system of two-variable linear equations in mathematics learning at SMP Negeri 1 Banjarmasin are assessed based on critical thinking indicators consisting of four indicators namely (1) interpreting, (2) analyzing, (3) evaluating, and (4) inference. As for the frequency distribution of students' critical thinking skills in learning using the PBL model is presented in Table 2.

Table 2. Frequency Distribution of Critical Thinking Ability

\begin{tabular}{cccr}
\hline Value & Qualification & Frequency & $\begin{array}{c}\text { Percentage } \\
(\boldsymbol{\%})\end{array}$ \\
\hline $85.01-100.00$ & Very Good & 10. & 30.30 \\
$70.01-85.00$ & Good & 9 & 27.27 \\
$55.01-70.00$ & Sufficient & 11 & 33,33 \\
$40.01-55.00$ & Less & 3 & 0.10 \\
$00.00-40.00$ & Very Less & 0 & 0.00 \\
& Total & $\mathbf{3 3}$ & $\mathbf{1 0 0 . 0 0}$
\end{tabular}

Based on Table 2 it can be seen that from 33 students who took mathematics learning using PBL models in class VIII B, SMP Negeri 1 Banjarmasin, there are almost $58 \%$ of students whose critical thinking skills are classified as very good and good qualifications, while the rest are in poor qualifications and very poor qualifications. The following is an example of one student's answer:

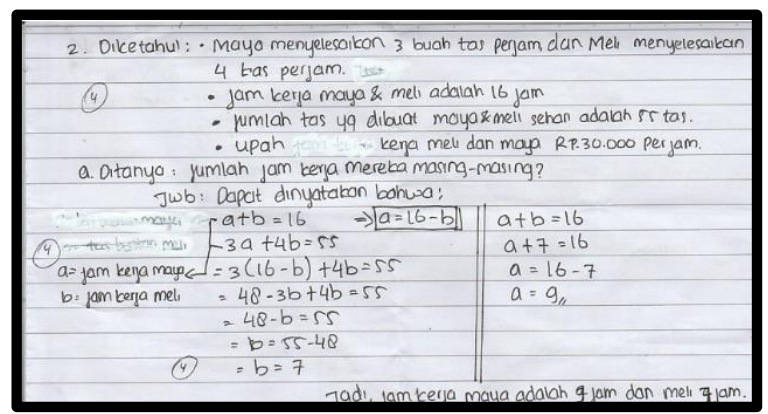

Fig. 1. An example of one of the students' answers

In Figure 1, it can be seen that the student gets the maximum score for each indicator of critical thinking ability, that is, the indicator of interpreting, analyzing, evaluating and evaluating. The student is able to write what is known and asked of the problem accurately and completely, make a mathematical model of the problem given and give an exact explanation, use the right strategy in solving problems and correct in making calculations, and is able to make conclusions precisely and completely, in accordance with the context of the problem given.

The results of evaluating students' critical thinking skills in learning mathematics using PBL models on the material system of two-variable linear equations for each indicator of critical thinking skills in class VIII B in SMP Negeri 1 Banjarmasin are shown in the following Table 3.

Table 3. Average Achievement of Each Indicator for Critical Thinking Ability

\begin{tabular}{clcc}
\hline No & $\begin{array}{c}\text { Critical Thinking Skills } \\
\text { Indicators }\end{array}$ & $\begin{array}{c}\text { Average } \\
\text { Achievement }\end{array}$ & Qualifying \\
\hline 1 & Interpretative & 89.65 & Very Good \\
2 & Analyzing & 58.58 & Pretty \\
3 & Evaluating & 80.81 & Good \\
4 & Menginferensi & 59.85 & Pretty \\
& average & $\mathbf{7 2 . 2 2}$ & Good \\
\hline
\end{tabular}

Based on Table 3 can be seen that out of the four indicators critical thinking skills there are two indicators that the average achievement is included insufficient qualifications namely the indicator of analyzing and inferencing, and there is one indicator that the average achievement is included in a very good qualification namely interpreting indicators. In interpreting indicators, most students can write what is known and asked of the questions precisely and completely. This means that most students can understand the purpose of the problem well. The analyzing indicator is the ability to identify the relationships between statements, questions, and concepts provided in the problem shown by making 
mathematical models correctly and giving explanations correctly. In this case, some students have been able to make mathematical models of the problems given, but most of them still have errors in giving explanations related to the modeling they made. This is because most students are not careful enough to solve the problems so that there are parts of the questions that are forgotten to explain mathematical modeling. The indicators evaluate the average student uses the right strategy in solving problems but makes mistakes in calculations. As for the indicators inference based on the scores obtained, many students do not write down the conclusions of the given problem.

From the overall achievement of the indicators, the average value of the achievement of critical thinking abilities of students in class VIII B of SMP Negeri 1 Banjarmasin is 72.22 and is in good qualifications. This is because during the learning process by applying the PBL model, students' critical thinking skills can work optimally. At the time of the learning process, students are accustomed to thinking and finding their own problems given by the PBL learning syntax that is learning begins with the student's orientation to the problem. The teacher only acts as a facilitator. At the last stage of the PBL model, there is a stage of analyzing and evaluating which is also an indicator of critical thinking skills. Also, the results of this study are in line with the opinion of [19] that one of the advantages of this problem-based learning model can develop students' ability to think critically. Other research state that PBL models of teaching is more effective for teaching mathematics. By adopting PBL models in teaching mathematics teacher can create a number of creative thinkers, critical decision makers, problem solvers which is very much needed for the competitive world [20]

\section{Conclusion}

Based on the analysis of research data shows that the students' critical thinking skills in mathematics using PBL models in class VIII SMPN 1 Banjarmasin learning year 2018/2019 are in good qualifications.

\section{References}

[1] E. Aizikovitsh-Udi and M. Amit, 'Developing the skills of critical and creative thinking by probability teaching', in Procedia - Social and Behavioral Sciences, 2011.

[2] G. S. Aktaş and M. Ünlü, 'Critical Thinking Skills of Teacher Candidates of Elementary Mathematics',
Procedia - Soc. Behav. Sci., vol. 93, pp. 831-835, 2013.

[3] S. Massa, 'The Development of Critical Thinking in Primary School: The Role of Teachers' Beliefs', Procedia - Soc. Behav. Sci., vol. 141, pp. 387-392, 2014.

[4] N. Dinuță, 'The use of critical thinking in teaching geometric concepts in primary school', Procedia - Soc. Behav. Sci., vol. 180, no. November 2014, pp. 788-794, 2015.

[5] L. O'Hare and C. McGuinness, 'The validity of critical thinking tests for predicting degree performance: A longitudinal study', Int. J. Educ. Res., vol. 72, pp. 162 $172,2015$.

[6] E. Altintas and A. S. Ozdemir, 'The Effect of Teaching with the Mathematics Activity Based on Purdue Model on Critical Thinking Skills and Mathematics Problem Solving Attitudes of Gifted and Non-Gifted Students', Procedia - Soc. Behav. Sci., vol. 46, pp. 853-857, 2012.

[7] E. E. Peter, 'Critical thinking: Essence for Teaching Mathematics and Mathematics Problem Solving Skills', African J. Math. Comput. Sci. Res., vol. 5, no. 3, pp. 3943, 2012.

[8] R. Ennis, 'Critical thinking', in Teaching philosophy, vol. 14, no. 1, 1991, pp. 5-24.

[9] S. Maharani, T. Nusantara, A. Rahman, and A. Qohar, 'Analyticity and Systematicity Students of Mathematics Education on Solving Non-routine Problems', Math. Stat., vol. 7, no. 2, pp. 50-55, 2019.

[10] R. A. Louis and J. M. Mistele, 'the Differences in Scores and Self-Efficacy By Student Gender in Mathematics and Science', Int. J. Sci. Math. Educ., vol. 10, no. 5, pp. 1163-1190, 2012.

[11] D. T. Tiruneh, M. De Cock, A. G. Weldeslassie, J. Elen, and R. Janssen, 'Measuring Critical Thinking in Physics: Development and Validation of a Critical Thinking Test in Electricity and Magnetism', Int. J. Sci. Math. Educ., vol. 15, no. 4, pp. 663-682, 2017.

[12] M. R. Noruzi and J. G. V. Hernandez, 'Critical Thinking in the Workplace: Characteristics, and Some Assessment Tests', in 3rd International Conference on Information and FInancial Engineering, 2011, vol. 12, pp. 19-20.

[13] P. Albergaria-Almeida, 'Critical thinking, questioning and creativity as components of intelligence', Procedia Soc. Behav. Sci., vol. 30, pp. 357-362, 2011.

[14] P. Facione, Critical Thinking: What It Is and Why It Counts. California: Measured Reason and The California Academic Press., 2011.

[15] P. A. Facione, C. A. Giancarlo, N. C. Facione, and J. Gainen, 'The disposition toward critical thinking', J. Gen. Educ., vol. 44, no. 1, pp. 1-17, 1995.

[16] R. . Arends, Learning to Teach. New York: Mc Graw Hill Companies, 2008. 
[17] D. Ismaimuza, 'Kemampuan Berpikir kritis Dan Kreatif Matematis Siswa SMP Melalui Pembelajaran Berbasis Masalah Dengan Strategi Konflik Kognitif', J. Teknol. (Sciences Eng., vol. 63, no. 2, pp. 33-37, 2013.

[18] R. Widyatiningtyas, Y. S. Kusumah, U. Sumarmo, and J. Sabandar, 'The Impact of Problem-based Learning Approach to Senior High School Studentes' Mathematic Critica Thinking Ability', J. Math. Educ. -, vol. 6, no. 2, pp. 30-38, 2015.

[19] N. M. Florea and E. Hurjui, 'Critical Thinking in Elementary School Children', Procedia - Soc. Behav. Sci., vol. 180, no. November 2014, pp. 565-572, 2015.

[20] R. D. Padmavathy and Mareesh.K, 'Effectiveness of Problem Based Learning In Mathematics', Int. Multidiscip. e-Journal, vol. 2, no. I, pp. 45-51, 2013. 